
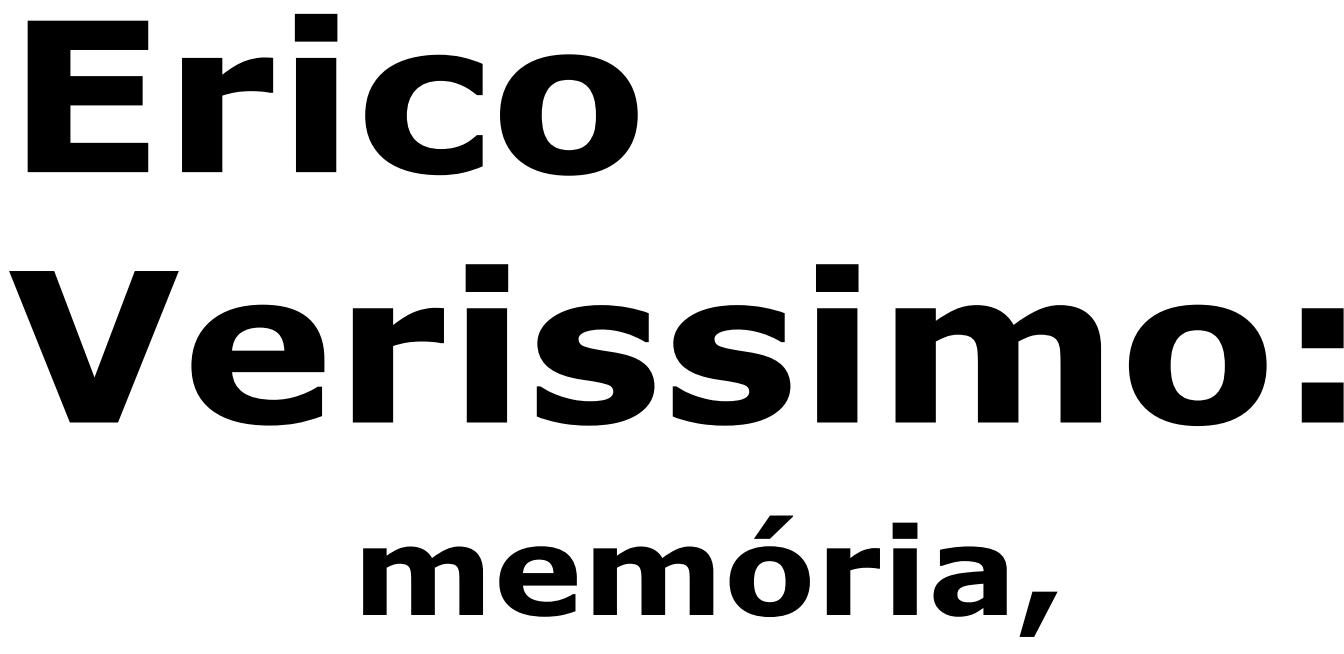

\title{
história e tempo
}

REGINA ZILBERMAN

é professora da PUC-RS.

\section{recuperado}

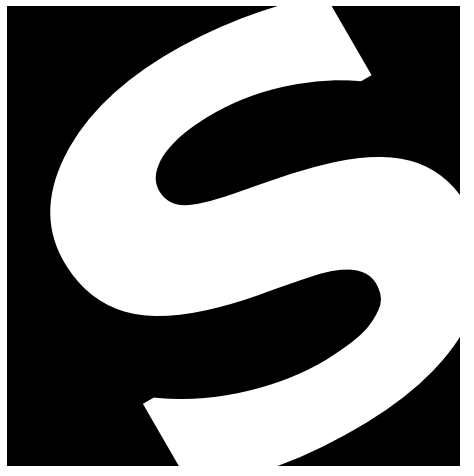

omente na última página do derradeiro volume de $O$ Arqui-

pélago, parte final de $O$ Tempo e

$o$ Vento, revela-se que o narrador

de OContinente, marco inicial da

saga criada por Erico Verissimo,

não era anônimo. Não apenas

dispõe de uma identidade, mas

pertence à família que constitui a matéria principal do romance:

trata-se de Floriano Terra Cambará, descendente direto dos heróicos

Pedro Missioneiro e Rodrigo Cambará, tetraneto de Bibiana Terra

Cambará e sobrinho-neto de Maria Valéria, a única personagem que atravessa a trilogia inteira.

$O$ Arquipélago encerra com a frase que abre $O$ Continente:

o narrador "sentou-se à máquina, ficou por alguns segundos a olhar para o papel, como que hipnotizado, e depois escreveu dum 
jato: "Era uma noite fria de lua cheia. As estrelas cintilavam sobre a cidade de Santa Fé, que de tão quieta e deserta parecia um cemitério abandonado" (Verissimo, 1962, t. 3, p. 1.014 - grifos do autor).

Publicada com quase quinze anos de diferença e ao final de uma trilogia que ela mesmo abrira (Verissimo, 1949, p. 3), a frase obriga o leitor a reiniciar a trilogia, porque, graças a esse artifício, a perspectiva muda. Anônimo, o narrador parecia distante de seu objeto; caracterizado agora como um indivíduo histórico, dotado de uma biografia profundamente vinculada à família cuja trajetória está relatando, ele não apenas se personaliza, mas também torna subjetivos e pessoais os julgamentos sobre as personagens do passado, a maioria das quais conheceu de modo indireto. O Arquipélago obriga à releitura de, pelo menos, $O$ Continente e, provavelmente, de $O R e$ trato, conferindo circularidade à narrativa, conforme um processo que compromete a linearidade do tempo-seja a da cronologia, seja a da própria leitura.

A estratégia utilizada na página de conclusão da trilogia assemelha-se à que Marcel Proust emprega no seu romance Em Busca do Tempo Perdido: a palavra final de O Tempo Redescoberto, último volume da obra, é a mesma que abre No Caminho de Swan, narrativa que inaugura o grupo de livros. A repetição da estratégia, por sua vez, deve-se a outra afinidade: ambas as personagens, o narrador da Recherche e Floriano, desejam afirmar-se como escritores e lutam para realizar a aptidão que acreditam possuir, mas que ainda não teria desabrochado com plenitude.

Para Jean-Yves Tadié (2000), a Recherche relata a história de uma vocação: o narrador, que, em apenas dois fugazes momentos, é designado como Marcel, busca, antes de tudo, o escritor que há nele, cuja obra talvez coincida com o romance que estamos lendo. Erico Verissimo parece dar a resposta a essa questão: Floriano, romancista por profissão, mas até então insatisfeito com o que publicara, não apenas confirma, no último parágrafo, seu pendor literário; ele também deixa claro que $O$ Tempo e o Vento, ainda que narrado em terceira pessoa, é o livro de sua vida, o texto que sempre desejara redigir.

Sob esse aspecto, Erico Verissimo parece dever a Marcel Proust algumas idéias, dívida antecipada pela apropriação da palavrachave da Recherche - tempo - que migra do título do livro francês para o brasileiro e que se completa pelos tópicos realçados até aqui:

1) Os narradores dos dois romances são escritores frustrados que somente ao final se revelam como responsáveis pela obra que estamos lendo; o mise-en-abyme de Prousté antecipado pelo relato em primeira pessoa e pelas sucessivas reflexões e discussões sobre a natureza da arte, da escrita e da leitura. Verissimoé mais discreto: o escritor, Floriano, aparece em $O$ Retrato e desenvolve-se em toda sua extensão tão-somente em $O$ Arquipélago, tomando conta dos episódios finais do último volume da trilogia. 
2) Arevelação é deixada para o último parágrafo das respectivas obras, provocandoum efeito de surpresa e uma pergunta: coincide o projeto de livros desses dois escritores - 0 narrador da Recherche e Floriano - ou eles ainda terão de escrevê-lo? Nem sempre os intérpretes de Proust coincidem na resposta a essa questão; mas Erico é taxativo: sim, Floriano é o autor de O Tempo e o Vento, personagem doravante responsável por tudo o que pode ser atribuído ao narrador - julgamentos, descrições, acertos e erros. Delegam-se a autoria e a propriedade, permitindo que o autor histórico esconda-se no anonimato.

Sob esse aspecto, Verissimo parece não apenas responder à pergunta que os estudiosos lançam à obra de Marcel Proust; ele também inverte o procedimento do antecessor. Porque, se, na Recherche, somos induzidos a identificar o narrador ao autor da obra, circunstância reforçada pelas duas situações em que Albertine, em A Prisioneira, nomeia seu amante, chamando-o de Marcel (1964), em $O$ Tempo e o Vento, Erico esconde-se sob a máscara da personagem e transfere a Floriano todos os méritos imputáveis à sua criação artística.

3) Coincidem a abertura e a conclusão do livro, por meio da repetição das palavras finais. Na obra de Proust, é a palavra tempo que inaugura e fecha o conjunto de sete volumes, além de se apresentar de modo direto ou indireto (graças ao emprego de advérbios e locuções adverbiais de tempo ou de conjunções temporais) no começo dos romances intermediários. Na trilogia de Erico Verissimo, como se observou, Floriano enceta o romance projetado com o período que lemos no princípio de "O Sobrado", capítulo primeiro de O Continente. $\mathrm{O}$ artifício determina a circularidade da escrita, como se a obra continuamente remetesse a si mesma, rejeitando a linearidade cronológica com que vinha se apresentando até então.

Esse último aspecto impõe um modo particular de leitura, já que essa é obrigada a recomeçar, sendo que, no retorno, altera-se a posição do leitor. Ele é induzido a rever seus juízos e a duvidar das idéias que até aqui formara. É igualmente motivado a mobilizar sua memória do tempo e do passado, configurado pelo material de que se apropriara até então, oferecido pelo narrador, mas, agora, passível de questionamento e revisão.

Em todos esses casos, está em questão o papel da memória diante da história:

- competiu à memória o armazenamento dos dados de que se compõem as duas narrativas, sendo que os dois romancistas viram-se obrigados a refletir sobre ela e estabelecer os critérios para sua incorporação ao relato;

- competiu à memória o armazenamento dos dados absorvidos durante a leitura, sendo que o leitor das duas obras vê-se perante a necessidade de se reposicionar diante da história narrada, seja essa a história privada dos próprios narradores, seja a história coletiva que eles vivenciaram e deram a conhecer.

A memória é o outro dos elos a unificar as duas obras, envolvendo o leitor e induzindo a uma reflexão sobre sua natureza, no modo como os romances a representam.

\section{EM BUSCA DA MEMÓRIA}

As últimas linhas de $O$ Arquipélago, ao revelarem para o leitor que a trilogia - ou, ao menos, $O$ Continente - foi redigida por Floriano Terra Cambará, indicam que a obra resulta do trabalho de um escritor profissional. Assim, se a estratégia narrativa aproxima $O$ Tempo $e$ Vento e o romance de MarcelProust, Em Busca do Tempo Perdido, uma sutil diferença se estabelece: Floriano já está inserido no sistema de produção da literatura, é conhecido como autor de sucesso, e sua ficção é avaliada pelos leitores, alguns mais rigorosos que outros, como sua cunhada, Sílvia Cambará, ou o amigo Roque Bandeira, o Tio Bicho, com quem o filho de Rodrigo Cambará discute virtudes e defeitos artísticos. Floriano, contudo, está insatisfeito com o que criou até então. Se, ao contrário do narrador de 
Proust, já conta com um catálogo de livros publicados, tal como o antecessor, ainda não descobriu sua vocação particular, tema que Jean-Yves Tadié considera básico para o entendimento da trajetória do protagonista da Recherche.

Para chegar a essa descoberta, Floriano precisa retornar no tempo, por intermédio de um processo de regressão. Contudo, o percurso a perfazer não se restringe à sua biografia. Essa corresponde aoúltimo elo de uma cadeia, cujo início poderia ser colocado numa dessas pontas: ela teria começado duzentos anos antes, com o nascimento do fundador mítico da família; ou bem depois, com a ação de um antepassado que ele, Floriano, tivera a oportunidade de conhecer pessoalmente, tratando-se nesse caso de Licurgo Cambará, seu avô.

Essas questões suscitam uma espécie de busca - recherche - a que Floriano precisa se dispor. E determinam igualmente a necessidade de articular os resultados da pesquisa ao produto já realizado, pois, quando Floriano principia, ficticiamente, a escrever $O$ Continente, o livro propriamente dito não só está pronto, como foi publicado e conta com uma recepção favorável consolidada. O final remete ao começo, mas é esse começo que aparece no final. Isso significa uma escrita que anda para trás, porque cada peça colocada à frente precisa mostrar coerência com o que foi exibido antecipadamente. Corresponde a uma operação matemática invertida, como uma equação cuja incógnita é previamente revelada, cabendo ajustá-la aos valores necessários, porém, desconhecidos, para resolvê-la. Qualquer falha durante o processo de solução compromete o resultado, por expor contradições do enredo e evidenciar inverossimilhanças.

O perigo é contornado pelas sucessivas alusões, em $O$ Arquipélago, a eventos apresentados nos volumes anteriores. No “Cadernode PautaSimples”, Florianoexpressa, para si mesmo, o projeto de seu livro, anunciando passagens que, na sua perspectiva, farão parte da obra em gestação, mas que o leitor já conhece, se chegou ao último volume da trilogia, depois de percorrer os dois anteriores. Nas conversas com Roque Bandeira, por sua vez, ele discute que perspectiva adotar, elegendo a terceira pessoa do discurso, para que o romance não se confunda com a autobiografia do narrador.

Até aqui, Floriano, vestindo as penas de pavão que Erico Verissimo lhe empresta, joga com cartas marcadas. Se $O$ Continente foi escrito em terceira pessoa, é preciso explicar, em $O$ Arquipélago, por que essa opção foi feita, matéria de reflexão interior no confessional "Caderno de Pauta Simples": “Oromance que estou projetandonãopode, não deve ser autobiográfico. Usar a terceira pessoa, isso sim" (Verissimo, 1962, t. 3, p. 241 - grifos do autor). E se a ação se inicia duzentos anos antes, com o nascimento de Pedro, pode-se inserir uma cena adicional, relativa à geração de Pedro Missioneiro e ao acolhimento da índia grávida na missão guarani, onde nascerá o ancestral mítico da família:

"1745. No topo duma coxilha, uma índia grávida, perdida no imenso deserto verde do Continente. O filho que traz no ventre é dum aventureiro paulista que a preou, emprenhou e abandonou.

Acriança nasce na redução jesuítica de São Miguel, onde a bugra busca refúgio. A mãe morre durante o parto, esvaída em sangue. Afonte... Porque esse bastardo, ummenino, virá a ser um dos troncos da família que vai ocupar o primeiro plano do romance, $e$ que bem poderá ser (ou parecer-se com) o clã dos Terra-Cambará" (Verissimo, 1962, t. 3, p. 747 - grifos do autor).

Se o processo da escrita requer uma regressão no tempo, não há como evitar a interface entre o assunto histórico e a trajetória pessoal do escritor. Por isso, tal como na Recherche de Proust, faz-se necessário o retorno à infância, introduzido, em $O$ Arquipélago, pela cena de "Reunião de Família I”, narrada em terceira pessoa, em que Floriano visita a livraria Lanterna de Diógenes e, sem se dar conta, compra, tal como fazia em criança, um caderno de pauta simples: 


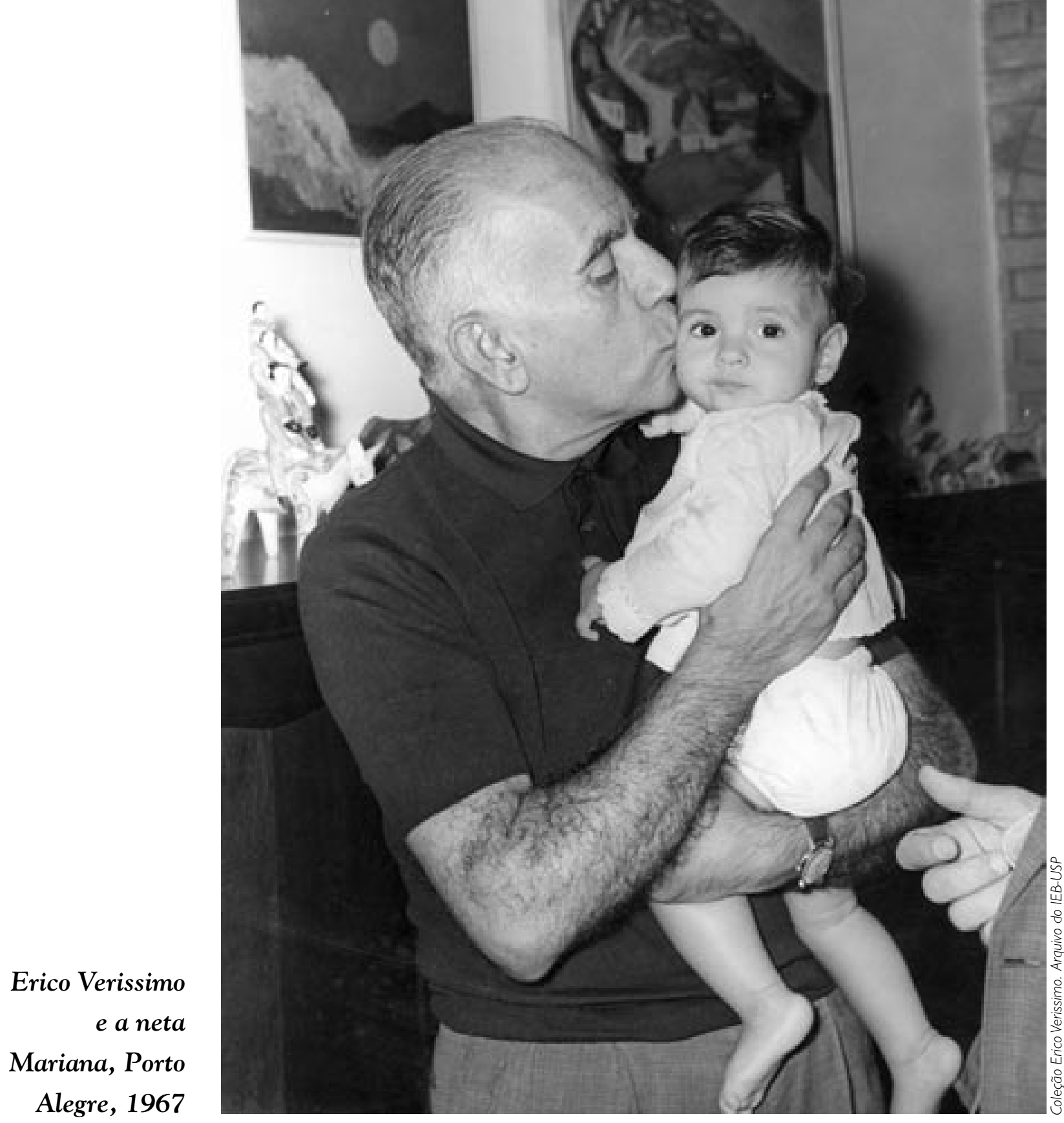

"Floriano lembra-se de um dia assinalado de sua vida. Tinha nove anos e a professora D. Revocata Assunção lhe dissera em plena aula: 'Seu Floriano, agora que o senhor sabe escrever, pode comprar um caderno de pauta simples.' Finalmente! Aquele era um de seus grandes sonhos: escrever sobre linhas simples, como a professora, como papai, como os grandes! Munido de dinheiro, encaminhou-se para A Lanterna de Diógenes, pisando duro, sentindo-se homem, orgulhoso de fazer aquela compra sozinho.

Floriano olha agora, distraído, para as velhas prateleiras, quando ouve uma voz:
- Que é que o senhor deseja?

[...] Responde automaticamente:

- Um caderno de pauta simples.

Floriano paga, apanha o pacote e sai, sorrindo. A cena lhe parece tão extraordinária que ele não quer comentá-la nem consigo mesmo" (Verissimo, 1962, t. 3, p. 46).

Logo a seguir, abre-se o primeiro segmento de "Caderno de Pauta Simples". Esse núcleo é, todo ele, grifado em itálico, apresentação gráfica similar à que é usada, em $O$ Continente, para interpolar, após os episódios que tratam da trajetória da família Terra Cambará, os acontecimentos histó- 
ricos, comentar a reação popular suscitada por aqueles fatos e introduzir o percurso dos Carés, representantes da camada popular, alheios, de certo modo, à história de que fazem parte. Pode-se cogitar que, na passagem de $O$ Continente para $O$ Arquipélago, Erico Verissimo não apenas alterou o acidente geográfico que dá nome aos volumes; mudou também o registro coletivo próprio àqueles segmentos - que manifesta a, digamos, vox populi - pelo registro pessoal que dá conta do processo de criação de Floriano, por extensão, do romance que será elaborado ou já foi lido. Narrado em primeira pessoa, a frase inicial do "Caderno de Pauta Simples" explica o incidente da livraria: “Quem guiou meus passos para dentro da Lanterna de Diógenes foi o Menino que ainda habita em mim" (Verissimo, 1962, t. 3, p. 59 - grifos do autor).

A essa declaração, seguem-se as recordações da infância, expostas conforme uma linguagem lírica, que mescla a percepção da criança à expressão sintética própria à poesia. Metamorfoseado no Menino, imagem que o escritor faz de si mesmo nessa faixa etária, Floriano faz aos poucos emergir seu projeto literário, concluindo o primeiro segmento com versos que aproximam a evocação do passado à abertura da Recherche de Proust:

"Ó noites da infância!
quarto escuro
fantasmas
sonhos
mistério"

(Verissimo, 1962,t.3, p. 63-grifos doautor).

O segundo segmento, pertencente também ao primeiro volume de $O$ Arquipélago, não altera profundamente o tom, em que se misturam evocações da infância e linguagem lírica, como se, para tratar daquele período da vida, fosse necessário mudar o registro lingüístico. Porém, Floriano parece dar-se conta de que as penas do pavão, devidas nesse caso a outro escritor, Marcel Proust, agora podem se mostrar inconvenientes. Por isso, depois de afirmar, nos parágrafos iniciais, que seu romance serviria para ajudá-lo a compreender "as ilhas do arquipélago a que pertenço" (Verissimo, 1962, t. 3, p. 237 - grifos do autor), decide que deve fugir da autobiografia e "evitar a cilada que a saudade nos arma, fazendo-nos cair no perigoso alçapão da infância" (Verissimo, 1962, t. 3, p. 241 - grifos do autor).

A regressão à infância tem teor catártico e, ainda que se prolongue pelo segundo volume de $O$ Arquipélago, visa a justificar o abandono da trilha autobiográfica e memorialista a que o romance projetado poderia estar rumando. É como se o escritor cortejasse a poética intimista empregada por Proust e, depois, a desdenhasse, conforme outra modalidade de catarse, não a da personagem, mas a do criador que há em Floriano.

Relegando as penas de pavão ao esquecimento, Floriano assume inteiramente a pele do escritor. O ato final desse processoconsiste na escolha, para ocupar o lugar de frase de encerramento da trilogia, da frase de abertura de $O$ Continente. Essa eleição, embora sugerida e antecipada por vários trechos do “Caderno de Pauta Simples" e dos diálogos com Roque Bandeira, é crucial, porque, doravante, a lógica da narrativa original não pode ser mais desmentida. Pelo contrário, ela terá de ser confirmada, não pelo começo que se transformou em final, mas pela forma que dá conta do começo de tudo.

É que $O$ Continente não se inicia por uma frase, e sim por uma estrutura, marcada pela duplicidade dos passados. Um primeiro passadoé o que abre com a frase reproduzida ao final de $O$ Arquipélago, correspondendo ao primeiro segmento de "O Sobrado", que relata a resistência oferecida por Licurgo Cambará às forças federalistas, quando sua moradia está assediada pelo exército inimigo. Floriano narra, em sucessivos segmentos que ocupam todo $O$ Continente, a prova glorificante de seu avô, aquela que o colocou na liderança política de Santa Fé, abrindo caminho para as gerações subseqüentes, da qual faz parte, dominarem a vida da cidade na condição de poder dirigente.

O primeiro segmento de "O Sobrado", que toma vinte páginas, abre-se com a frase mencionada, não encerra, mas é in- 
terrompido, quando os filhos de Licurgo, os meninos Toríbio e Rodrigo, conversam, e o menor, no futuro o pai de Floriano, revela ao irmão possuir uma arma preciosa, um punhal muito antigo:

“Toríbio procura a mão de Rodrigo por baixo das cobertas e seus dedos tocam um objeto frio.

- Que é isso?

- O punhal.

- [...] Finco-lhe a ponta na garganta. Eu já vi sangrar um boi.

Ao imaginar essas coisas o coração de Rodrigo pulsa com mais força. Ele vê o sangue escorrendo da goela do maragato. E seus pequenos dedos apertam o cabo do punhal" (Verissimo, 1949, p. 21).

Um corte de tipo cinematográfico conduz o leitor à cena seguinte, protagonizada pelo padre Alonso, jesuíta em Sete Povos das Missões e proprietário do punhal que, páginas antes e 150 anos depois, está nas mãos de Rodrigo Terra Cambará, o pai de Floriano, o futuro escritor. Após espinhoso diálogo com seu confessor, padre Antônio, Alonzo relembra a sorte da arma: fora o instrumento que, por pouco, não usara para matar, ainda quando residia na Espanha, um adversário e que trouxera para a América, na qualidade de penhor de um crime quase cometido.

O punhal constitui o primeiro de uma série de objetos que se transmitem de uma geração a outra de Cambarás. É, contudo, o único que atravessa o romance das primeiras às últimas páginas. Pedro Missioneiro apropria-se dele ao fugir das missões guaranis, em vias de serem ocupadas pelos soldados portugueses, após a derrocada da experiência catequética dos jesuítas. Pedro, o menino indígena que recebera o nome do rival de Alonzo, como forma de esse purgar sua culpa, é, agora adulto, igualmente o herdeiro do objeto mágico que ligará passado e presente por se transmitir de pai para filho:

"Três meses depois, quando o exército dos Sete Povos já haviam sido completamente desbaratados numa batalha campal, [...] - Pedro montou num cavalo baio e, levando consigo apenas a roupa do corpo, a chirimia e o punhal de prata, fugiu a todo o galope na direção do grande rio[...]" (Verissimo, 1949, p. 59).

A transmissão do punhal, objeto que sinaliza permanentemente a ameaça de morte que acompanha as personagens masculinas em $O$ Continente, confere a Alonzo o papel de pai simbólico de Pedro Missioneiro. A associação de Alonzo ao sagrado, somada às habilidades sobrenaturais manifestadas por Pedro, desde a infância, outorgam ao índio propriedades de herói mítico. Como é de sua relação com Ana Terra que nasce Pedro Terra, pai de Bibiana e sogro de Rodrigo Cambará, cabe-lhe igualmente a função de ancestral totêmico da família, cuja trajetória Floriano virá a narrar.

Outro começo, mais primitivo, instalase, e um segundo passado apresenta-se, exigindo ser narrado. A passagem de um a outro tempo - o da história política para o da origem mítica - é facultada pela revelação do punhal, que, na ordem do tempo, migrou, até chegar às mãos de Rodrigo Terra Cambará, o último herói do clã a que Floriano pertence; e que, na ordem do discurso, permitiu à narrativa regredir aos primórdios da formação do grupo, ao início que não supõe nenhuma anterioridade. Assim, em $O$ Tempo e o Vento, o punhal do padre Alonzo, carregado por Pedro Missioneiro, exerce a função da madeleine, na Recherche, pois aciona a memória e possibilita o trânsito e o entrelaçamento das temporalidades, sem o que a narrativa do passado não se faz possível.

Da madeleine o punhal carrega a propriedade de entrelaçar os tempos; traz também a marca da degradação que acompanha a trajetória dos Terra Cambará, após a tomada do poder por Licurgo, ao final de $O$ Continente. Eis por que a referência derradeira à arma ocorre nas páginas finais de $O$ Arquipélago, quando Eduardo, o irmão comunista de Floriano, está reunido com os companheiros na célula do Partido, em Santa Fé: 
"Na casa dum operário da firma Spielvogel \& Filhos, na Rua das Missões, Eduardo Cambará confabulava com um grupo de camaradas, entre os quais se encontrava um neto do Cel. Cacique Fagundes recém-inscrito no Partido Comunista. Era um rapaz de tipo indiático, de pouco mais de vinte anos. Aquela reunião, que tinha todo o ar duma conspiração, deixava-o excitado.

Fazia calor. A mulher do operário serviu guaranás. Eduardo tirou o casaco, deixando à mostra o punhal que, de hábito, trazia preso à cinta. O jovem Fagundes pediu para ver a arma. Revolveu-a nas mãos, olhou o lavor do cabo de prata, passou os dedos pela lâmina e por fim perguntou se aquele era o famoso punhal que, segundo rezava a tradição, estava com a família Terra-Cambará havia quase duzentos anos. Eduardo deu-lhe uma resposta breve e distraída. Estava examinando com interesse uma lista de nomes de pessoas da cidade e do municípío que simpatizavam com a causa do comunismo e que, dum modo ou de outro, poderiam ajudá-la. Por fim, reclinando-se contra o respaldo da cadeira, disse:

- Bom, precisamos estar preparados para o que vem por aí. Estou convencido de que o novo governo vai pôr o Partido fora da lei. Oneto de Cacique Fagundes, que tinha ainda na mão o punhal, escutava-o fascinado, com uma expressão febril nos olhos oblíquos" (Verissimo, 1962, t. 3, pp. 1.009-10).

A cena parece reproduzir outra, colocada no primeiro episódio da cronologia de $O$ Continente, "A Fonte", em que Pedro, ainda menino e residente em Sete Povos das Missões, contempla, com fascínio similar, o punhal de Alonzo, o mesmo que, no final do segmento, leva consigo ao fugir da redução em chamas:

“O espírito de Pedro não se concentrava no trabalho. Nem o espírito nem os olhos, pois estes estavam fitos, fascinados, no punhal de prata que se achava em cima da mesa da cela.

Sempre que podia, Pedro entrava furtivamente na cela do padre, tomava o punhal nas mãos, acariciava-o, experimentava-lhe a ponta, punha-o na cintura e imaginava-se um guerreiro como o Corregedor, o alferes real Tiaraju, que era o homem que ele mais admirava na redução.

Pedro ficava-se ali na cela a imaginar essas coisas. Depois repunha o punhal sobre a mesa e retirava-se sem ruído, como uma sombra" (Verissimo, 1949, pp. 45-6).

Pode-se supor que, pela imaginação do jovem Fagundes, de ascendência indígena, também transitassem as fantasias que povoam a mente de Pedro Missioneiro, ainda criança. A situação das personagens não guarda apenas essas semelhanças; como observa Eduardo, descendente, aliás, do sonhador Pedro, o grupo de comunistas está prestes a cair na clandestinidade, assim como os guaranis de Sete Povos estavam, em 1750, quando a ação narrada se passa, em vias de aniquilação por força dos exércitos combinados de Portugal e Espanha.

Eis o outro lado da circularidade narrativa proposta em $O$ Tempo e o Vento. Observe-se que a cena protagonizada por Eduardo e o neto de Cacique Fagundes, não nomeado, ocorre na noite de Ano Bom, logo, ao mesmo tempo em que Floriano, na mansarda onde costuma se refugiar para refletir ou escrever, inicia a composição do livro. Por intermédio desse recurso, retomam-se os dois tempos com que a narrativa iniciara, em $O$ Continente:

- a trajetória secular dos Terra Cambará, equivalente ao primeiro passado, encontra seu redator, completando-se o ciclo iniciado por Licurgo, em "O Sobrado”, o espaço representando aqui o lugar de início e termo da família;

- a trajetória histórica, matéria do segundo passado, desemboca, por sua vez, em nova conspiração e desejo de mudança, de que são portadores personagens de extração popular e vinculados às etnias formadoras da região.

Os dois tempos apresentam, ambos, construção circular: Floriano remete ao começo da leitura, o punhal de Eduardo, cobiçado pelo jovem Fagundes, ao começo da história. Em ambos os casos, a memória 
é o elemento unificador, mas, na obra de Erico Verissimo, ela transcende o âmbito pessoal, até porque sua madeleine - transfigurada no punhal de prata - é objeto que circula entre homens, atravessando grupos sociais e mudando de portador. Pode, por isso, simbolizar a história que o livro quer igualmente retratar.

\section{DA MEMÓRIA PARA A HISTÓRIA}

Para poder redigir o livro que vai salvar sua carreira de escritor e pacificá-lo interiormente (pois permitirá a reconciliação com o pai, com o irmão Jango e com Sílvia, a mulher amada com quem não teve coragem de casar, atitude de que, agora, se arrepende), Floriano não pode confiar apenas em sua memória pessoal. Ele bem que tenta, começando o "Caderno de Pauta Simples" por um esforço de regredir à infância e resgatar suas impressões originais da família e das outras pessoas com quem, em criança, se relacionava.

O processo de regressão não se frustra completamente porque mostra que, se percorresse essa via, daria com os costados na mesma literatura intimista e desfibrada que vinha praticando até então. $O$ fato de conferir ao punhal o papel desempenhado pela madeleine já é expressivo da mudança, pois, enquanto o biscoito, no texto de Proust, desencadeia associações e sensações percebíveis apenas pelo narrador, a arma pode evidenciar um sentido apreensível pelo grupo, seja o familiar, seja o social. A madeleine sofre o desgaste natural do tempo, da situação especial em que aparece e de sua condição perecível, enquanto o punhal, por sua resistência e durabilidade, pode cruzar o tempo, apontando para as relações existentes entre as várias etapas da história.

A rejeição do intimismo, do relato em primeira pessoa e da autobiografia determina a escolha de um outro modelo de gatilho para a memória. Pela mesmarazão, cabe encontrar outra fonte, para além do próprio eu, dada a precariedade e limitação desse; define-se, assim, o papel atribuído a Maria Valéria.
Essa personagem aparece nas primeiras páginas de $O$ Continente desempenhando função vital em "O Sobrado": é a mulher lúcida e combativa, que desafia o poder de Licurgo, embora nutra recolhida paixão pelo cunhado. Essa caracterização inicial sugere, desde já, que, se de um lado ela reproduz as mulheres que a antecederam, como Ana Terra e Bibiana Cambará, por outro, antecipa o comportamento de Floriano: também ele ousa afrontar o senhor do Sobrado - seu pai, Rodrigo Terra Cambará - como alimenta recolhido amor pela cunhada, Sílvia, casada com Jango, o irmão responsável pela manutenção do Angico, a fazenda da família, e quase um duplo de Licurgo, seu avô.

Maria Valéria, ao lado de Licurgo e dos dois filhos desse, Toríbio e Rodrigo, migra para $O$ Retrato e, depois, para $O$ Arquipélago. As três personagens masculinas morrem durante o transcurso dos três tomos do último volume de $O$ Tempo $e$ o Vento, mas não a velha senhora, cuja função esclarece-se nos capítulos de "Caderno de Pauta Simples".

No primeiro segmento, Floriano sublinha a influência que exercera na sua formação, apresentando, de modo singelo, os valores que regerão seu comportamento:

“Mas para o Menino toda a sabedoria da vida concentrava-se em duas mulheres: a Dinda e a Laurinda. Tinham a última palavra em matéria de Teologia, Cosmogonia, Meteorologia, Astronomia e outros 'ias' e enigmas" (Verissimo, 1962, t. 1, p. 62 - grifos do autor).

E reproduzindo seus ditados, entre os quais se destaca o que regula o seu destino:

"Mas entre todos os ditados da Dinda, um havia que deixava o Menino pensativo.

Cada qual enterra seu pai como pode" (Verissimo, 1962, t.1, p. 63 - grifos do autor).

Maria Valéria não sintetiza apenas a sabedoria e o bom senso; ela igualmente responsabiliza-se pela conservação do passado, razão por que é a ela que Floria- 
no recorre quando deseja conhecer figuras e enredos da família, como os que dizem respeito a Bibiana e "seu marido, um certo Cap. Rodrigo, aventureiro, espadachim, mulherengo, homem de coragem extraordinária e apetites insaciáveis", ou a "outros antepassados mais longínquos, como essa quase lendária Ana Terra, minha pentavó, que a tradição aponta como um dos fundadores de Santa Fê"' (Verissimo, 1962, t. 3, p. 748 - grifos do autor).

Maria Valéria não retém apenas a memória dos fatos; ela preserva igualmente os vestígios do passado, corporificados nos objetos que sintetizam os sujeitos que os portaram. Esses objetos, verdadeira memorabilia da família Terra Cambará, estão armazenados num baú, cuja chave só ela possui e a que apenas Floriano tem acesso:

"Depois de muitas hesitações e resmungos, a Dinda me confia a chave do baú de lata em que traz guardadas suas lembranças e relíquias. Encontro nele, de mistura com incontáveis bugigangas [...], importantes peças do museu da família, como o dólmã militar do Cap. Rodrigo, um xale que pertenceu a D. Bibiana, e uma camisa de homem, de pano grosseiro e encardido. (Éa que meu bisavô Bolívar Cambará vestia no dia em que foi assassinado pelos capangas dos Amarais, e que sua mãe guardou, assim esburacadade balas e manchada de sangue como estava.) Todas essas coisas naturalmente me excitam a fantasia pelas suas possibilidades novelescas, mas concentro a atenção principalmente nas cartas, nos recortes de jornais e nos daguerreótipos que descubro dentro duma caixa de sândalo, no fundo do baú" (Verissimo, 1962, t. 3, p. 748 - grifos do autor).

Não por outra razão Roque Bandeira, nas primeiras páginas de $O$ Arquipélago, qualifica a tia-avó de Floriano de "vestal do Sobrado, que mantém acesa a chama sagrada de sua vela... É uma espécie de farol em cima dum rochedo, batido pelo vento e pelo tempo..." (Verissimo, 1962, t. 1, p. 19). Assim definida, Maria Valéria aparece como o oposto de OTempo e o Vento, símbolo da resistência à perecibilidade a que estão submetidas pessoas e coisas. Nada mais representativo da memória e da permanência, tarefas de que ela se incumbe sem fraquejar.

Fonte da memória, ela se confunde com a matéria que preserva. Confunde-se também com o próprio Floriano, como duplo da ação do sobrinho-neto, a quem se mescla, constituindo, pois, a unidade que garante a narrativa da história. Graças a essa fusão, a memória vai em busca da história, e a narrativa acontece. Sem a confluência entre a memória e seu narrador, não emerge a história, nem se faz o livro.

\section{BIBLIOGRAFIA}

PROUST, Marcel. A Prisioneira. Trad. Lourdes Sousa de Alencar e Manuel Bandeira. 2aed. Porto Alegre, Globo, 1964

(Em Busca do Tempo Perdido, 5).

TADIÉ, Jean-Yves. Proust et le Roman. Paris, Gallimard, 2000 (1971).

VERISSIMO, Erico. O Continente. Porto Alegre, Globo, 1949.

. 0 Arquipélago. Porto Alegre, Globo, 1962. 